\title{
PENGARUH PERSONALITY, BUDAYA ORGANISASI DAN KOMITMEN ORGANISASI TERHADAP ORGANIZATIONAL CITIZENSHIP BEHAVIOR SERTA DAMPAKNYA TERHADAP KINERJA GURU PADA SEKOLAH MENENGAH DI KECAMATAN INDRA MAKMUR KABUPATEN ACEH TIMUR
}

\author{
Puji Satria $^{1}$, Faisal Matriadi $^{2^{*}}$, Maryudi $^{3}$ \\ ${ }^{1}$ Mahasiswa Pascasarjana Ilmu Manajemen Universitas Malikussaleh \\ ${ }^{23}$ Dosen Pascasarjana Ilmu Manajemen Universitas Malikussaleh \\ Email: poejisatria@gmail.com ${ }^{1}$, faisalmatriadi@gmail.com ${ }^{2}$, maryudi@unimal.ac.id ${ }^{3}$
}

\begin{abstract}
The purpose of this study was to determine and analyze the influence of personality, organizational culture and organizational commitment on organizational citizenship behavior and teacher performance in high schools in Indra Makmur District, North Aceh Regency. The number of samples in this study were 126 teachers obtained by saturated sample technique. The data analysis method used was Structural Equation Modeling (SEM) using AMOS 21 software. The results of this study found that directly, personality and organizational culture had a positive and significant effect on organizational citizenship behavior, while organizational culture has no significant effect. Furthermore, the results of the study found that personality and organizational citizenship behavior had a positive effect on teacher performance, but organizational culture had a negative effect and organizational commitment had no significant effect. The results of the mediation effect test found that organizational citizenship behavior is able to fully mediate the influence of organizational culture and personality on performance, but not to be a mediator on the effect of organizational commitment on theacher performance.
\end{abstract}

Keywords : Personality, Organizational Culture, Organizational Commintment, Organizational Citizenship Behavior and Theacher Performance

Salah satu unsur yang sangat penting dalam sebuah organisasi adalah sumber daya manusia (Ridwan et al., 2018). Pengelolaan sumber daya manusia dalam organisasi menjadi hal yang penting untuk diketahui demi mencapai kemajuan organisasi (Brewster et al., 2016). Masalah SDM saat ini masih tetap menjadi pusat perhatian bagi suatu organisasi untuk bertahan di era globalisasi yang diiringi dengan tingkat persaingan yang semakin ketat (Sudiastawan et al., 2016). Kemajuan organisasi juga akan tercapai apabila sumber daya manusia memiliki kinerja yang baik (Mondiani, 2012; Manurung \& Riani, 2017). Akan tetapi, apabila kinerja sumber daya manusia tidak baik maka akan berimbas pada pencapaian tujuan organisasi (Manzoor et al., 2011).

Pendidikan pada era modern merupakan kebutuhan yang harus dipenuhi. Matriadi \& Dalimunthe (2017) berpendapat bahwa guru yang profesional merupakan guru yang mengedepankan mutu kualitas pendidikan yang didasarkan pada potensi dan kecakapan individu. Capaian kinerja guru yang baik merefleksikan keberhasilan pemerintah dalam meningkatkan kualitas pendidikan di Indonesia (Matriadi \& Dalimunthe, 2017). Kinerja sendiri merupakan hasil refleksi dari hasil kerja (Mangkunegara, 2009). Uraian tersebut menunjukkan bahwa kinerja guru menjadi aspek penting dalam meningkatkan mutu pendidikan bagi suatu negeri, sehingga perlu diketahui faktor-faktor apa saja yang dapat mempengaruhi kinerja guru.

Secara teoritis, terdapat beberapa faktor yang mempengaruhi kinerja individu. Mahmudi (2007) berpendapat bahwa kinerja dipengaruhi oleh faktor kepribadian individu itu sendiri. Mulyani dan Soliha (2014) berpendapat bahwa kinerja dipengaruhi oleh faktor organisasi, seperti budaya organisasi dan komitmen organisasional. Bambale et al. (2012) berpendapat bahwa kinerja dipengaruhi oleh faktor perilaku anggota organisasi, seperti perilaku saling membantu secara sukarela, atau secara teoritis dinamakan Organizational Citizen Behavior (OCB). Berdasarkan uraian tersebut, penulis menduga bahwa faktor-faktor yang dapat mempengaruhi kinerja guru adalah personality, budaya organisasi, komitmen organisasi dan OCB. 
Studi-studi sebelumnya juga telah mengkaji pengaruh personality, budaya organisasi, komitmen organisasi dan OCB terhadap kinerja serta membuktikan membuktikan bahwa personality, budaya organisasi, komitmen organisasi dan OCB memberikan pengaruh signifikan terhadap kinerja (Khan et al., 2010; Tindowen, 2019; Minarsih, 2015; Ngatinah dan Purnami, 2019; Yusuf, 2016; Sutomo, 2013). Akan tetapi, terdapat juga beberapa studi yang mendokumentasikan hasil yang berbeda, dimana personality, budaya organisasi, komitmen organisasi dan OCB tidak berpengaruh signifikan terhadap kinerja (Wicaksono \& Surjanti, 2018; Shahzad et al., 2013; Ticoalu, 2013; Ramadhan et al., 2018). Hal ini menunjukkan bahwa masih terjadi perdebatan antar para peneliti mengenai pengaruh personality, budaya organisasi, komitmen organisasi dan OCB terhadap kinerja, sehingga mendorong penulis untuk mengkajinya kembali.

Uraian teoritis di atas memperkuat bahwasanya personality, budaya organisasi, komitmen organisasi dan OCB menjadi faktor yang mempengaruhi kinerja. Maka dari itu, penulis mencoba menganalisis variabel tersebut pada objek penelitian, yaitu guru sekolah menengan di Kecamatan Indra Makmur, Kabupaten Aceh Timur. Hal ini dikarenakan masih belum optimalnya aspek-aspek tersebut pada guru-guru sekolah menengan di Kecamatan Indra Makmur. Berdasarkan hasil observasi awal (2019), ditemukan bahwa sebagian besar guru-guru telah memiliki kinerja yang cukup baik. Akan tetapi, masih terdapat sebagian guru yang memiliki kinerja di bawah rata-rata.

Belum optimalnya kinerja juga diikuti dengan perilaku ekstra peran yang belum begitu tercipta di lingkungan sekolah. Berdasarkan hasil observasi awal yang telah dilakukan di sekolah menengan yang adal di Kecamatan Indra Makmur, terdapat sebagian guru yang masih belum memiliki inisiatif membantu rekan guru lainnya yang berhalangan untuk mengajar. Selain itu, sebagian guru juga memiliki hubungan yang kurang baik dengan guru lainnya, sehingga hal tersebut menghambat terjadinya perilaku ekstra peran di lingkungan sekolah.

Selanjutnya, kepribadian guru juga mengalami sedikit permasalahan. Berdasarkan hasil observasi awal yang telah dilakukan di sekolah menengan yang adal di Kecamatan Indra Makmur, sebagian besar guru telah memiliki tingkat kepribadian yang baik, akan tetapi terdapat beberapa guru yang belum memiliki kepribadian selayaknya sebagai pengajar/pendidik. Hal ini dapat dilihat dari masih terdapat sikap yang kurang baik di sebagian kecil guru, dikarenakan konflik-konflik internal atau pribadi yang terjadi. Selain itu, ditemukan juga sebagian kecil guru yang belum terlalu mau untuk bergaul dengan rekan guru lainnya.

Selanjutnya, permasalahan budaya organisasi juga terjadi di sekolah menengah di Kecamatan Indra Makmur. Hasil observasi awal menemukan bahwa masih terdapat sebagian kecil guru yang merasa bahwa guru lain tidak menghargainya, hal ini membuat budaya organisai belum tergolong pada kondisi yang baik. Selain itu, sebagian kecil guru masih belum terbiasa dengan kegiatankegiatan yang rutin dilakukan oleh sekolah, seperti kegiatan yang khususnya berhubungan dengan minat bakat siswa, dimana partisipasi sebagian kecil guru yang masih kurang pada program-pragram tersebut.

Permasalahan juga terjadi pada komitmen organisasional guru sekolah menengah di Kecamatan Indra Makmur. Hasil observasi awal yang telah dilakukan menemukan bahwa sebagian besar guru telah memiliki kesamaan nilai dengan sekolah, akan tetapi terdapat sebagian kecil yang belum memiliki kesamaan nilai dan tujuan dengan tujuan sekolah, dimana sebagian kecil guru tersebut masih belum mencintai profesi sebagai guru dan masih memiliki keinginan untuk berpindah, baik ke sekolah lain ataupun ke organisasi lain. Ini menunjukkan bahwa komtimen organisasi guru masih terbilang belum begitu baik.

\section{LANDASAN TEORITIS DAN HIPOTESIS \\ Hubungan Personality dan OCB}

Wardani dan Suseno (2012) menyebutkan bahwa keinginan pegawai untuk membantu rekan kerja (perilaku OCB) sangat dipengaruhi oleh Personality dan suasana hati (mood). Personality dipandang sebagai salah satu karakter diri yang cenderung stabil dan menetap, sedangkan mood itu dapat berubah-ubah, sehingga faktor personality dapat memberikan pengaruh yang lebih stabil dan bertahan pada OCB.

Penelitian oleh Kumar et al. (2009) menguji extraversion, agreeableness. Conscientiousness, openness to experience pada sifat-sifat dari personality merupaka prediktor yang positif dan signifikan bagi terbentuknya perilaku OCB. Demikian juga halnya dengan penelitian yang dilakukan 
oleh Najari et al. (2011) menemukan bahwa seluruh big five of traits dari personality berpengaruh secara parsial dan simultan terhadap OCB pegawai yang bekerja di organisasi publik Iran. Berdasarkan kajian teoritis dan beberapa penelitian sebelumnya, maka pernyataan hipotesis pertama dalam penelitian ini adalah:

$\mathrm{H}_{1}$ : Personality berpengaruh signifikan terhadap OCB pada Sekolah Menengah di Kecamatan indra Makmu Kabupaten Aceh Timur

\section{Hubungan Budaya Organsasi dan OCB}

Budaya organisasi bisa dikatakan sebagai salah satu elemen penting yang terdapat didalam organisasi, karena budaya akan menentukan cara-cara pegawainya dalam berperilaku. Penelitian Mohanty dan Rath (2012) menemukan bahwa budaya organisasi berpengaruh positif terhadap OCB pada pekerja-pekerja diketiga sektor tersebut.

Budaya organisasi merupakan suatu kondisi awal yang memicu terjadinya OCB pada individu, dimana pada budaya organisasi yang positif, pegawai merasa lebih ingin melakukan pekerjaanya melebihi apa yang telah disyaratkan dalam job description. Penelitian yang dilakukan oleh Oemar (2013) menemukan bahwa pengaruh yang signifikan dan positif antara budaya organisasi terhadap OCB PNS dimaksud.

Berdasarkan kajian teoritis dan beberapa penelitian sebelumnya, maka pernyataan hipotesis kedua dalam penelitian ini adalah:

$\mathrm{H}_{2}$ : Budaya Organisasi berpengaruh signifikan terhadap OCB pada Sekolah Menengah di Kecamatan indra Makmu Kabupaten Aceh Timur

\section{Komitmen Organisasi dan OCB}

Lambert et al. (2008) mengatakan bahwa komitmen organisasi pada intinya mengacu pada loyalitas yang diberikan pegawai demi keberhasilan pencapaian tujuan dan kesuksesan suatu organisasi. Pegawai yang memiliki loyalitas atau komitmen yang tinggi terhadap organisasinya tercermin pada keterlibatan pegawai (ikut mengambil bagian) dalam menyelesaikan permasalahan organisasi diluar peugasan umum, sehingga pegawai memandang dirinya merasa penting memberikan kontribusi pekerjaan yang lebih (extra role) bagi kesuksesan organisasi.

Penelitian yang dilakukan Oemar (2013) menunjukkan bahwa komitmen organisasi berpengaruh positif dan signifikan terhadap OCB. Penelitian Rezaiean et al. (2010) menemukan bahwa komitmen organisasi memiliki pengaruh positif secara langsung dan signifikan terhadap OCB. Demikian juga penelitian yang dilakukan oleh Jo dan Joo (2011) yang mendokumentasikan bahwa komitmen organisasi secara signifikan berpengaruh terhadap OCB. Berdasarkan kajian teoritis dan beberapa penelitian sebelumnya, maka pernyataan hipotesis ketiga dalam penelitian ini adalah:

$\mathrm{H}_{3}$ : Komitmen Organisasi berpengaruh signifikan terhadap OCB pada Sekolah Menengah di Kecamatan indra Makmu Kabupaten Aceh Timur

\section{Persnonality dan Kinerja Guru}

Luthans (2006) berpendapat bahwa individu dengan ciri-ciri bekerja keras, disiplin tinggi, giat dan bertanggung jawab akan memiliki suatu kinerja yang lebih tinggi dibandingkan dengan individu kebalikannya. Individu dengan sifat malas atau tidak disiplin terlihat negatif yang menunjukkan mereka tidak memiliki motivasi dan tanggung jawab dalam bekerja.

Poropat (2009) mengungkapkan bahwa individu yang memiliki tingakt emosi yang tinggi (neuroticism), pada umumnya mereka akan lebih cemas dan cenderung untuk berfokus mengontrol emosi mereka, sehingga akibat kekhawatiran atas fokus tersebut, akan berdampak pada berkurangnya fokus terhadap kinerja.

Penelitian oleh Jiang et al (2009) bertujuan ingin mengklarifikasi apakah sifat conscientiousness dan agreableness dari personality memberikan pengaruh terhadap kinerja trainer yang bekerja di institusi pelatihan publik pemerintah China. Hasil penelitiannya mengklaim bahwa sifat conscientiousness memberikan efek pengaruh yang positif terhadap 
kinerja pegawai. Sedangkan agreableness ternyata memiliki pengaruh negatif pada kinerja pegawai-pegawai dimaksud.

Berdasarkan kajian teoritis dan beberapa penelitian sebelumnya, maka pernyataan hipotesis keempat dalam penelitian ini adalah:

$\mathrm{H}_{4}$ : Personality berpengaruh signifikan terhadap Kinerja Pegawai pada Sekolah Menengah di Kecamatan indra Makmu Kabupaten Aceh Timur

\section{Budaya Organisasi dan Kinerja Guru}

Indrawijaya (2010) berpendapat, budaya yang terbentuk berdasarkan jiwa solidaritas senasib dan sepenanggungan, maka budaya akan dijadikan panutan dan dijunjung tiinggi oleh setiap pegawai. Budaya juga dijadikan sebagai alat pemersatu diantara mereka, peredam konflik, dan motivator agar pegawai dapat melaksanakan tugas dengan baik. Budaya yang kuat mampu mengarahkan pegawai untuk mempertahankan atau meningkatkan kinerja mereka masing-masing sesuai dengan nilai-nilai yang terkandung pada budaya.

Berbeda dengan Robbins (2006) yang mengemukakan bahwa jika budaya organisasi terbentuk pertama kali oleh pendiri organisasi, maka budaya merupakan tempat bernaungnya filosofifilosofi organisasi. Filosofi mencakup visi dan misi organisasi yang menjadi sumber kekuatan penting dalam berkompentisi. Organisasi dengan budaya kuat akan mampu mendoronh dan membentuk perilaku pegawai supaya memiliki kinerja tertentu sesuai dengan harapan organisasi.

Penelitian oleh Shahzad et al. (2013) menemukan bahwa pengaruh yang positif dan signifikan terhadap kinerja pegawai-pegawai dimaksud. Harwiki (2013) berargumen bahwa budaya suatu organisasi dapat dipengaruhi oleh perilaku dan gaya-gaya kepemimpinan yang terdapat didalamnya. Lebih lanjut penelitian Harwiki (2013) menemukan bahwa komitmen organisasi dan kinerja pegawai. Berdasarkan kajian teoritis dan beberapa penelitian sebelumnya, maka pernyataan hipotesis kelima dalam penelitian ini adalah:

$\mathrm{H}_{5} \quad$ : Budaya organisasi berpengaruh signifikan terhadap Kinerja Pegawai pada Sekolah Menengah di Kecamatan indra Makmu Kabupaten Aceh Timur

\section{Hubungan Komitmen Organisasi dan Kinerja Guru}

Bakshi et al. (2011) menggaris bawahi bahwa jika membandingkan pengawai yang memiliki komitmen rendah, maka pegawai dengan tingkat komitmen tinggi akan terkontaminasi dengan banyaknya kualitas pengalaman mereka dalam menyelesaikan pekerjaan-pekerjaan. Pegawai dengan tingkat komitmen tinggi aka terdorong untuk melakukan sesuatu yang didasari atas komitmen mereka terhadap organisasi, sehingga cenderung memiliki kinerja yang lebih menonjol (positif) melampaui harapan organisasi.

Penelitian yang dilakukan oleh Khan et al. (2010), menemukan cukup bukti bahwa komitmen organisasi memiliki pengaruh yang positif terhadap kinerja di Pakistan. Demikian juga dengan penelitian Sani (2013) yang menemukan bahwa komitmen organisasi berpengaruh langsung secara signifikan terhadap kinerja pegawai-pegawai dimaksud. Berdasarkan kajian teoritis dan beberapa penelitian sebelumnya, maka pernyataan hipotesis keenam dalam penelitian ini adalah:

$\mathrm{H}_{6}$ : Komitmen Organisasi berpengaruh signifikan terhadap Kinerja Pegawai pada Sekolah Menengah di Kecamatan indra Makmu Kabupaten Aceh Timur

\section{Hubungan OCB dengan Kinerja Guru}

Bambale et al. (2012) menyatakan pegawai denga OCB dikategorikan sebagai pegawai yang senantiasa mendukung dan memelihara semangat kepentingan organisasi. Munculnya keefisienan dan keefektifan atau fungsi-fungsi organisasi merupakan dampak positif yang bersumber dari kinerjakinerja pegawai dimaksud. Pegawai denga OCB akan menunjukkan perilaku gemar membantu rekan kerja yang terlihat tidak produktif sehingga kinerja pegawai yang dibantu dapat meningkat. Pegawai dengan OCB juga bersedia secara suka rela untuk bekerja lembur, karena demi menjaga kinerja yang dimilikinya (Griffin dan Moorheas, 2012). Tehran et al.(2013) juga menunjukkan bukti yang cukup bahwa seluruh dimensi OCB meiliki hubungan yang signifikan terhadap kinerja pegawai. Berdasarkan kajian teoritis dan beberapa penelitian sebelumnya, maka pernyataan hipotesis ketujuh dalam penelitian ini adalah:

$\mathrm{H}_{7}$ : OCB berpengaruh signifikan terhadap Kinerja Pegawai pada Sekolah Menengah di Kecamatan Indra Makmu Kabupaten Aceh Timur

OCB Memediasi Hubungan Peronality dan Kinerja Guru 
Kumar et al. (2009) menggunkan indikator conscientiousness, extraversion, agreeableness, emotional stability pada personality menunjukkan pengaruh pada OCB, sedangkan Openess to experince tidak memiliki hubungan pengaruh signifikan. Penelitian lain yang dilakukan oleh Darsana (2013) pada lembaga perbankan (sektor bisnis) dengan subjek adalah pegawai non leader yang tersebar di 30 kantor BPR di Gianyar Bali menunjukkan OCB berperan positif dalam memediasi pengaruh variabel personality dan Budaya organisasi terhadap kinerja pegawai secara tidak langsung. Berdasarkan kajian teoritis dan beberapa penelitian sebelumnya, maka pernyataan hipotesis kedelapan dalam penelitian ini adalah:

$\mathrm{H}_{8} \quad$ : OCB memediasi pengaruh Personality terhadap Kinerja Pegawai pada Sekolah Menengah di Kecamatan Indra Makmu Kabupaten Aceh Timur

\section{OCB Memediasi Hubungan Budaya Organisasi dan Kinerja Guru}

Penelitian yang dilakukan oleh Harwiki (2013) yang dilakukan pada 249 pegawai yang mewakili 25 koperasi ternama di Propinsi Jawa Timur, Indonesia, menunjukkan budaya organisasi berpengaruh signifikan terhadap OCB dan kinerja pegawai koperasi-koperasi. Darsana (2013) berdasarkan penelitian pada lembaga perbankan (sektor Bisnis) dengan subjek adalah pegawai non leader yang tersebar di 30 kantor BPR di Gianyar Bali menunjukkan OCB berperan positif dalam memediasi variabel budaya organisasi terhadap kinerja pegawai secara tidak langsung. Berdasarkan kajian teoritis dan beberapa penelitian sebelumnya, maka pernyataan hipotesis kesembilan dalam penelitian ini adalah:

$\mathrm{H}_{9}$ : OCB memediasi BudayaOrganisasi terhadap Kinerja Pegawai melalui pada Sekolah Menengah di Kecamatan Indra Makmu Kabupaten Aceh Timur

\section{OCB Memediasi Hubungan Komitmen Organisasi dan Kinerja Guru}

Griffin dan Moorhead (2012) berpandangan bahwa pegawai yang memiliki komitmen dan OCB akan berdampak positif terhadap kinerja pegawai dan organisasinya. Mereka mencontohkan dengan mebandingkan tingkat kualitas dan kuantitas kinerja dari dua orang pegawai dalam bekerja. Pegawai pertama mempunyai komitmen untuk menyelesaikan setiap pekerjaan sesuai dengan jam kerjanya, di menolak untuk bekerja lembur (overtime) ataupun enggan membantu rekan kerja. Dengan kata lain dia tidak mau memberikan kontribusi diluar apa yang menjadi fokus pekerjaannya demi menjaga kuantitas dan kualitas kerja yang dimilikinya. Pegawai seperti ini bisa disebut sebagai pekerja yang bai (good performer) tetapi terlihat tidak memiliki OCB yang baik (good citizhenship). Maka dapat disimpulkan bahwa komitmen organisasi dapat mempengaruhi kenerja pegawai secara tidak langsung melalui OCB yang ditampilkan. Penelitian oleh Sani (2013) mengklaim bahwa OCB secara positif berperan dalam memediasi komitmen organisasi terhadap kinerja pegawai. Berdasarkan kajian teoritis dan beberapa penelitian sebelumnya, maka pernyataan hipotesis kesepuluh dalam penelitian ini adalah:

$\mathrm{H}_{10}$ : OCB memediasi pengaruh Komitmen Organisasi Terhadap Kinerja Pegawai pada Sekolah Menengah di Kecamatan Indra Makmu di Kabupaten Aceh Timur

\section{METODE PENELITIAN}

Lokasi penelitian ini adalah pada sekolah menengah di Kecamatan Indra Makmur Kabupaten Aceh Timur. Sedangkan yang menjadi objek penelitian adalah guru sekolah menengah yang mengajar pada Kecamatan Indra Makmu.

Populasi dan penelitian ini adalah seluruh guru sekolah menengah di Kecamatan Indra Makmu Kabupaten Aceh Timur yang berjumlah 126 orang. Sementara itu, Teknik pengambilan sampel dilakukan dengan menggunakan metode sensus (sensus sampling) atau istilah lainnya adalah sampel jenuh, yaitu teknik penentuan sampel bila seluruh anggota populasi dijadikan sebagai sampel (Sugiyono, 2015). Maka dari itu, sampel penelitian ini juga berjumlah 126 guru yang dapat dilihat pada tabel di bawah ini:

\section{Tabel 1.Jumlah Populasi dan Sampel Penelitian}

\begin{tabular}{ccc}
\hline No & Nama Sekolah & Jumlah Guru \\
\hline 1 & SMAN 1 Indra Makmu & 48 Orang \\
2 & SMKN 1 Indra Makmu & 26 Orang \\
3 & SMPN 1 Indra Makmu & 20 Orang \\
4 & SMPN 2 Indra Makmu & 20 Orang \\
5 & SMPN 3 Indra Makmu & 12 Orang \\
\hline \multicolumn{3}{c}{ Jumlah } \\
\hline \multicolumn{2}{c}{ Sumber: web dapo.dikdasmen.go.id }
\end{tabular}


Adapun definisi operasional variabel di dalam penelitian ini dapat dilihat pada tabel di bawah ini:

\section{Tabel 1}

Definisi Operasinal Variabel

\begin{tabular}{|c|c|c|c|c|}
\hline No & Variabel & Definisi Variabel & Indikator & Skala \\
\hline 1 & $\begin{array}{c}\text { Kinerja } \\
\text { Guru }\end{array}$ & $\begin{array}{l}\text { Kinerja guru } \\
\text { adalah } \\
\text { kemampuan guru } \\
\text { untuk } \\
\text { mendemonstrasika } \\
\text { n berbagai } \\
\text { kecakapan dan } \\
\text { kompetensi yang } \\
\text { dimilikinya } \\
\text { Depdiknas (2004: } \\
\text { 11) }\end{array}$ & $\begin{array}{l}\text { 1) Perencanaan } \\
\text { pembelajaran } \\
\text { 2) Pelaksanaan } \\
\text { Kegiatan } \\
\text { pembelajaran } \\
\text { 3) Penilaian } \\
\text { Pembelajaran } \\
\text { Matriadi (2017) }\end{array}$ & Likert \\
\hline 2 & OCB & $\begin{array}{l}\text { Perilaku individu } \\
\text { yang bersifat } \\
\text { bebas } \\
\text { (discretionary) } \\
\text { yang tidak secara } \\
\text { langsung atau } \\
\text { eksplisit mendapat } \\
\text { penghargaan dari } \\
\text { sistem imbalan } \\
\text { (reward) formal, } \\
\text { dan secara } \\
\text { keseluruhan } \\
\text { (agregat) akan } \\
\text { meningkatkan } \\
\text { efisiensi dan } \\
\text { efektifitas fungsi- } \\
\text { fungsi organisasi } \\
\text { (Organ et al, } \\
\text { 2006) }\end{array}$ & $\begin{array}{l}\text { 1. Altruism (Inisiatif } \\
\text { membatu rekan } \\
\text { kerja secara } \\
\text { sukarela) } \\
\text { 2. Conscientiousness } \\
\text { (Kehati-hatian } \\
\text { dalam berperilaku) } \\
\text { 3. Courtesy (menjaga } \\
\text { hubungan baik } \\
\text { dengan rekan kerja) } \\
\text { 4. Sportmanship } \\
\text { (Kesedian } \\
\text { menerima apapun } \\
\text { yang ditetapkan } \\
\text { organisasi } \\
\text { meskipun dengan } \\
\text { keadaan yang tidak } \\
\text { sewajarnya } \\
\text { 5. Civic virtue } \\
\text { (memiliki tanggung } \\
\text { jawab untuk terlibat } \\
\text { dan peduli dalam } \\
\text { berbagai kegiatan } \\
\text { yang } \\
\text { diselenggarakan } \\
\text { organisasi }\end{array}$ & Likert \\
\hline 3 & $\begin{array}{c}\text { Komitm } \\
\text { en } \\
\text { Organis } \\
\text { asi } \\
\text { (KO) }\end{array}$ & $\begin{array}{l}\text { Kekuatan yang } \\
\text { bersifat realtif dari } \\
\text { individu dalam } \\
\text { mengidentifikasik } \\
\text { an keterlibatan } \\
\text { dirinya kedalam } \\
\text { bagian organisasi. }\end{array}$ & $\begin{array}{lr}\text { 1) Kepercayaan yang } \\
\text { kuat dan } \\
\text { penerimaan } \\
\text { terhadap nilai-nilai } \\
\text { dan tujuan } \\
\text { organisasi } \\
\text { 2) Kesiapan dan } \\
\text { kesedian untuk } \\
\text { bersungguh- } \\
\text { sungguh atas nama } \\
\text { organisasi } \\
\text { 3) Keinginan yang }\end{array}$ & Likert \\
\hline
\end{tabular}




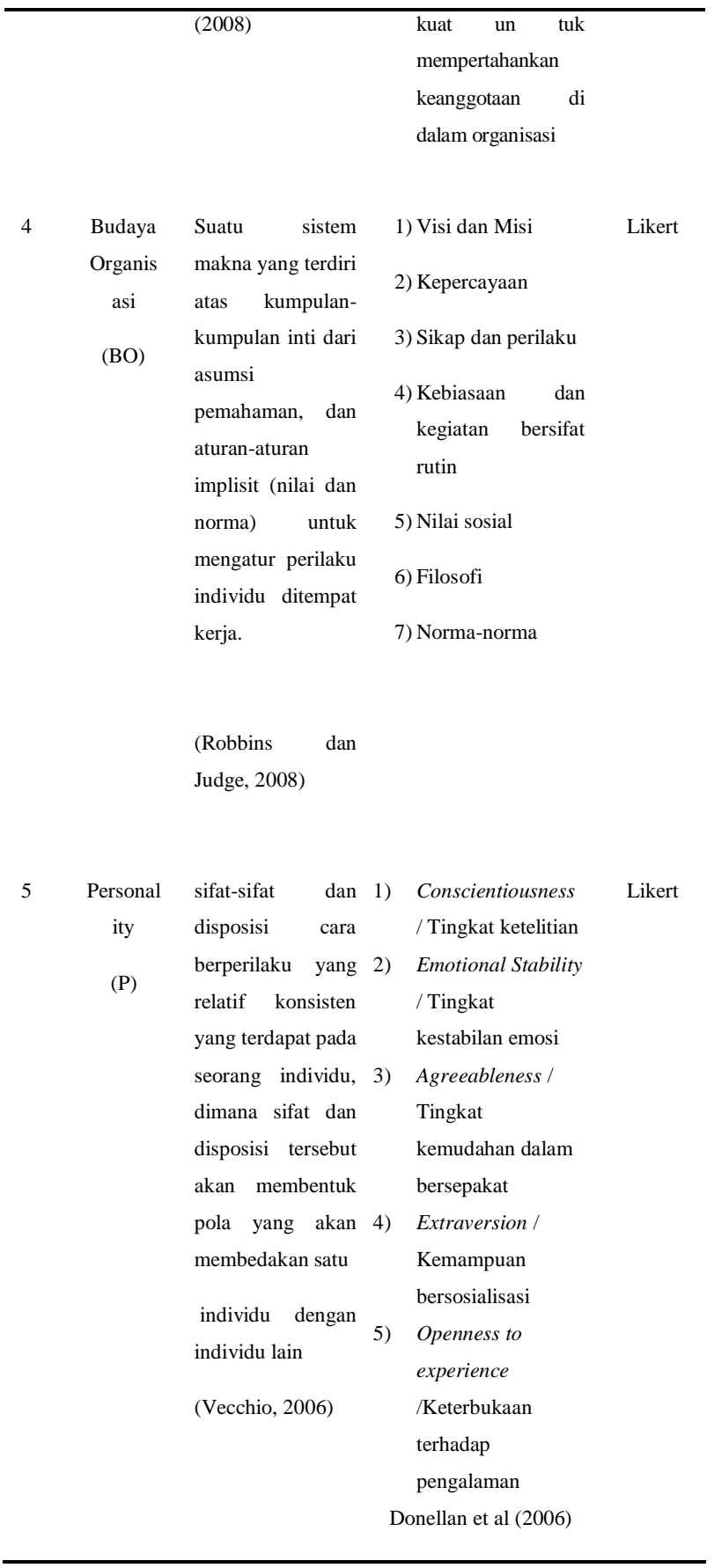

Teknik analisa data di antaranya digunakan adalah Structural Equation Modeling, dimana persamaan struktural dalam penelitian ini dapat dilihat sebagai berikut:

$\mathrm{OCB}=\mathrm{b}_{1} \mathrm{P}+\mathrm{b}_{2} \mathrm{KO}+\mathrm{b}_{3} \mathrm{BO}+\mathrm{Z}_{1}$

$\mathrm{KG}=\mathrm{b}_{1} \mathrm{P}+\mathrm{b}_{2} \mathrm{KO}+\mathrm{b}_{3} \mathrm{BO}+\mathrm{b}_{4} \mathrm{OCB}+\mathrm{Z}_{2}$

Keterangan:

$\begin{array}{ll}\text { KG } & =\text { Kinerja } \\ \mathrm{OCB} & =\text { Organizational Citizen Behavior } \\ \mathrm{P} & =\text { Personality } \\ \mathrm{KO} & =\text { Komitmen Organisasi } \\ \mathrm{BO} & =\text { Budaya Organisasi }\end{array}$


$\mathrm{b}_{1}-\mathrm{b}_{4}=$ Koefisien Estimasi

$\mathrm{Z}_{1} \mathrm{Z}_{2} \quad=$ Nilai residual

Sementara itu, full model dalam penelitian ini dapat dilihat sebagai berikut:

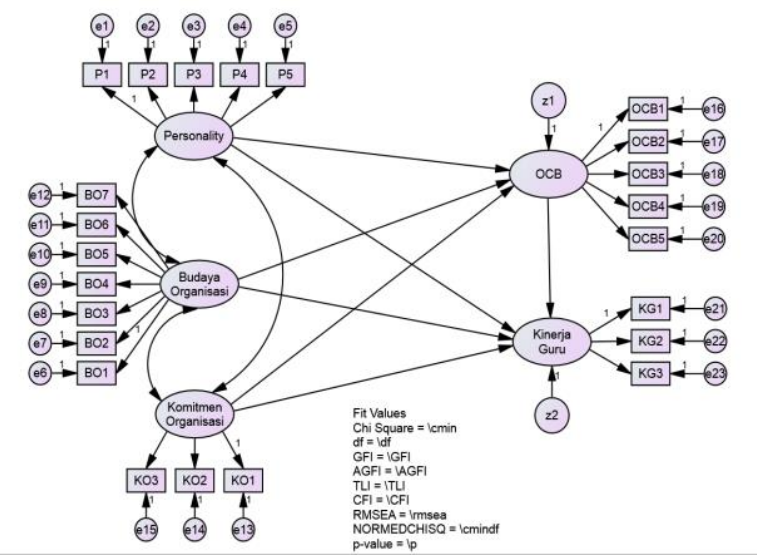

\section{Gambar 1 Full Model Penelitian}

\section{HASIL DAN PEMBAHASAN}

\section{Analisis Deskriptfi Responden}

Penelitian ini menemukan bahwa responden perempuan dalam penelitian ini sebanyak $60 \%$, sedangkan responden laki-laki sebanyak $40 \%$. Sementara itu, ditemukan bahwa guru berusia 21-30 tahun sebanyak 33\%, guru berusia 31-40 tahun sebanyak 46\%, guru berusia 41-50 Tahun sebanyak 7\% dan guru yang berusia 51-60 tahun sebanyak 14\%. Hasil ini menunjukkan bahwa guru Sekolah Menengah di Kecamatan Indra Makmur didominasi oleh guru yang berusia 31-40 tahun.

Sealnjutnya, berdasarkan status pernikahannya, ditemukan bahwa terdapat $66,7 \%$ responden yang telah menikah dan 33,30\% responden yang belum menikah. Adapun karakteristik responden berdasarkan tingkat pendidikannya yaitu $6,3 \%$ responden memiliki tingkat pendidikan pascasarjana, sedangkan 93,7\% responden memiliki tingkat pendidikan sarjana. Sementara itu, guru yang memiliki masa kerja di bawah 5 tahun sebanyak 6\%, masa kerja 6-10 tahun sebanyak 57\%, masa kerja 11-15 tahun sebanyak 17\%, masa kerja 16-20 tahun sebanyak 7\% dan masa kerja 21-25 tahun sebanyak 3\%.

\section{Confirmatory Factor Analysis}

Dalam SEM, pengujian validitas dilakukan dengan Confirmatory Factor Analysis (CFA) masing-masing konstruk, yaitu dengan melihat nilai Loading Factor dari indikator yang digunakan. Ghozali (2011) berpendapat bahwa indikator dikatakan valid apabila nilai loading factor berada lebih besar dari 0,60.

Hasil uji CFA untuk variabel seluruh indikator yang digunakan dalam penelitian ini memiliki nilai loading factor lebih besar dari pada 0,60 sehingga dapat dikatakan bahwa seluruh indikator yang digunakan telah valid.

\section{Uji Reliabilitas}

Uji reliabilitas dilakukan dengan tiga cara, yaitu construct reliability (CR), variance extracted (VE) dan descriminant validity (DV). Hasil perhitungan CR, VE dan DV untuk seluruh variabel dapat dilihat sebagai berikut:

\section{Tabel 2 Uji Reliabilitas}

Variabel construct variance descriminant




\begin{tabular}{lccc}
\hline & reliability $(\mathrm{CR})$ & extracted $(\mathrm{VE})$ & validity $(\mathrm{DV})$ \\
\hline Personality & 0,863 & 0,561 & 0,749 \\
Budaya Organisasi & 0,928 & 0,652 & 0,808 \\
Komitmen Organisasi & 0,839 & 0,639 & 0,799 \\
OCB & 0,883 & 0,603 & 0,776 \\
Kinerja Guru & 0,825 & 0,611 & 0,782 \\
\hline
\end{tabular}

Berdasarkan Tabel 2, ditemukan bahwa keseluruhan nilai CR berada di atas nilai 0,70 dan seluruh nilai VE berada di atas 0,50. Dengan demikian, keseluruhan konstruk dalam penelitian ini adalah reliabel sehingga model yang dibentuk adalah layak untuk digunakan.

\section{Pengujian Asumsi SEM}

\section{Uji Kesesuaian Sample}

Pada analisis SEM, ukuran sampel yang sesuai adalah 100-200 (Hair et al., 1999). Dalam penelitian ini, banyaknya sampel adalah 126 guru. Setalah dilakukan pengujian, tidak terdapat outlier data pada jawaban seluruh responden, sehingga sampel tetap sebanyak 126 guru. Hal ini menunjukkan bahwa penelitian ini memiliki ukuran sampel yang cukup dan susuai untuk dianalisis secara SEM.

\section{Uji Normalitas}

Dalam penelitian ini, evaluasi normalitas dilakukan dengan menggunakan critical ratio skewness dan kurtosis value sebesar $\pm 2,58$. Ditemukan bahwa nilai critical ratio skewness yang berada diluar rentang $\pm 2,58$. Dengan demikian, dapat disimpulkan bahwa keseluruhan data terdistribusi secara normal secara unvariate. Selanjutnya, nilai multivariate pada critical ratio kurtosis juga berada di rentang $\pm 2,58$ yaitu sebesar 2,795, sehingga dapat disimpulkan bahwa baik secara unvariate maupun multivariate data dalam penelitian ini berdistribusi secara normal.

\section{Uji Outlier Data}

Data ekstrim (outlier) adalah observasi yang muncul dengan nilai-nilai ekstrim., karena kombinasi karakteristik yang unik dan terlihat sangat jauh berbeda dengan observasiobservasi lainnya (Ferdinand, 2014). Dalam penelitian ini, pengujian outlier data dilakukan dengan uji Mahalanobis $d$-squared, dengan membandingkan nilai p1 dan p2. Nilai p1 atau p2 di atas, 0,05 menunjukkan bahwa tidak terdapat outlier data dalam suatu penelitian.

Hasil pengujian outlier data dengan Mahalanobis $d$-squared dalam penelitian ini dapat dilihat pada Lampiran 7. Hasil menunjukkan bahwa keseluruhan observasi memiliki nilai p1 atau p2 di atas 0,05 sehingga dapat disimpulkan bahwa tidak terdapat outlier data dalam penelitian ini.

\section{Uji Multikolinearitas}

Asumsi multikolinearitas mengharuskan tidak adanya korelasi yang sempurna atau besar di antara variabel-variabel independen. Hal ini dikarenakan variabel Model SEM sudah dikenakan matriks sebesar 1, maka semua pembobotan regresi yang dibakukan harus berada dalam cakupan plus atau minus 1. Dalam penelitian ini, deteksi multikolinearitas menggunakan nilai Determinan of Sampple Covariance Matrix, dimana nilai Determinan of Sampple Covariance Matrix yang menjauh dari 0 menunjukkan bahwa tidak terdapat multikolinearitas antar variabel endogen. Nilai Determinan of Sampple Covariance Matrix dalam penelitian ini sebesar 0,117 dimana nilai tersebut terbilang sangat jauh dari 0 , maka dapat dikatakan bahwa tidak terdapat gejala multikolineritas dalam penelitian ini. 


\section{UJI KESESUAIAN MODEL}

Hasil analisis SEM dalam penelitian ini menghasilkan full model sebagai berikut:

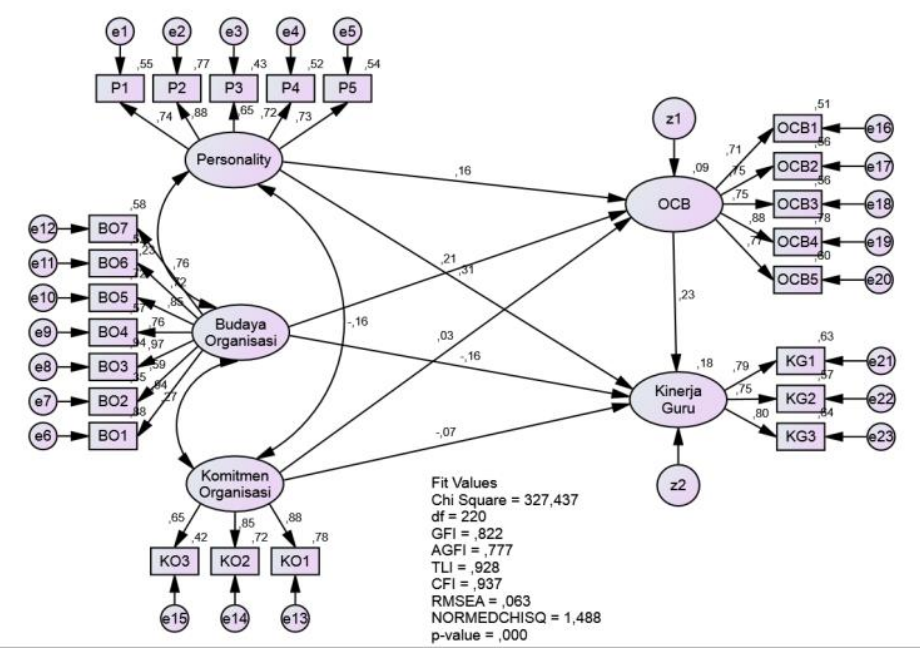

\section{Gambar 2 Full Model sebelum Modifikasi}

Adapun nilai GOF yang diperoleh adalah sebagai berikut:

Tabel 3 GOF Full Model Sebelum Modifikasi

\begin{tabular}{|c|c|c|c|c|}
\hline No & Kriteria & $\begin{array}{c}\text { Nilai } \\
\text { Diharapkan }\end{array}$ & Nilai Hasil & Kesimpulan \\
\hline 1 & Chi Square & $\begin{array}{c}\text { Diharapkan } \\
\text { Kecil }\end{array}$ & 327,437 & Baik \\
\hline 2 & $\begin{array}{l}\text { Goodness of Fit } \\
\text { Index (GFI) }\end{array}$ & $>0,90$ & 0,822 & Marginal \\
\hline 3 & $\begin{array}{l}\text { Adjusted } \\
\text { Goodness of Fit } \\
\text { Index (AGFI) }\end{array}$ & $>0,90$ & 0,777 & Buruk \\
\hline 4 & $\begin{array}{l}\text { Tucker Lewis } \\
\text { Index (TLI) }\end{array}$ & $>0,90$ & 0,928 & Baik \\
\hline 5 & $\begin{array}{l}\text { Comparative Fit } \\
\text { Index }(\mathrm{CFI})\end{array}$ & $>0.90$ & 0,937 & Baik \\
\hline 6 & $\begin{array}{l}\text { Root Mean Square } \\
\text { Error of } \\
\text { Approximation } \\
\text { (RMSEA) }\end{array}$ & $\leq 0,08$ & 0,063 & Baik \\
\hline 7 & CMIN/DF & $\leq 2$ & 1,488 & Baik \\
\hline
\end{tabular}

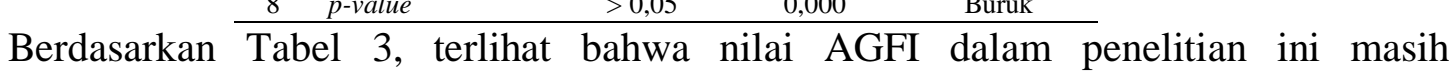
dikategorikan buruk, kemudian GOF pada Full Model masih belum dapat diterima dikarenakan nilai $p$-value jauh berada di 0,05. Maka dari itu, Full Model memerlukan modifikasi dengan unobserve variable menggunakan petunjuk covariances sesuai dengan 
hasil output pada Modification Indices. Adapun petunjuk modifikasi berdasarkan hasil analisis Modification Indices dapat dilihat pada tabel berikut:

Tabel 4 Modification Indice

\begin{tabular}{ccccc}
\hline & & & M.I. & $\begin{array}{c}\text { Par } \\
\text { Change }\end{array}$ \\
\hline e17 & $<-->$ & e18 & 23,914 &, 423 \\
e16 & $<->$ & e18 & 5,173 &,- 172 \\
e12 & $<->$ & e14 & 6,724 &, 158 \\
e12 & $<->$ & e13 & 5,561 &,- 144 \\
e10 & $<-->$ & e12 & 12,083 &, 208 \\
e10 & $<->$ & e11 & 13,192 &, 266 \\
e8 & $<-->$ & e11 & 5,025 &,- 106 \\
e6 & $<->$ & e10 & 7,218 &,- 096 \\
e6 & $<->$ & e8 & 12,484 &, 073 \\
e6 & $<->$ & e7 & 4,459 &,- 116 \\
e1 & $<->>$ & e4 & 4,359 &,- 179 \\
e1 & $<->$ & e3 & 4,814 &, 210
\end{tabular}

Hasil analisis full model setelah dilakukukan modifikasi dapat dilihat pada gambar berikut:

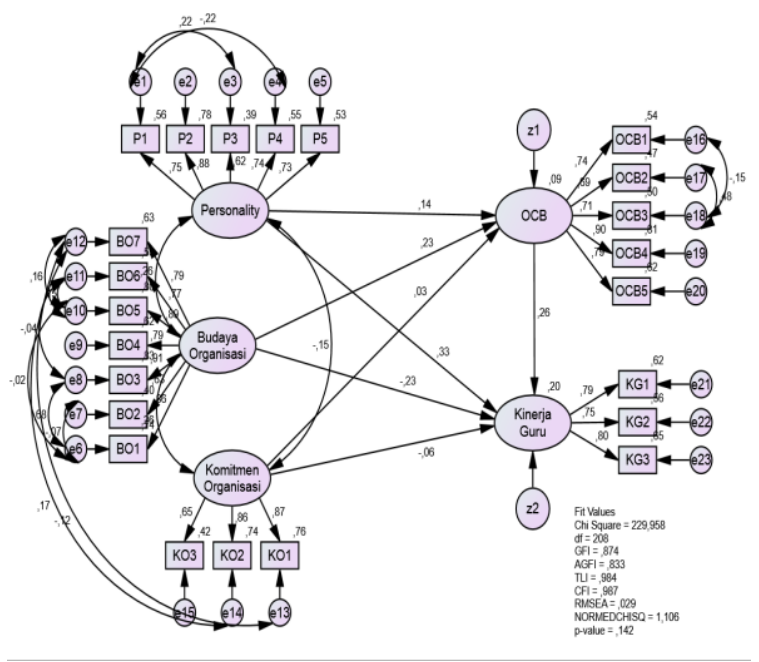

\section{Gambar 3 Full Model setelah Modifikasi}

Adapun nilai GOF yang diperoleh adalah sebagai berikut:

\section{Tabel 4 GOF untuk Full Model Setelah Modifikasi}

\begin{tabular}{llccc}
\hline \multirow{2}{*}{ No } & \multirow{2}{*}{ Kriteria } & Nilai & Nilai & \multirow{2}{*}{ Kesimpulan } \\
& & Diharapkan & Hasil & \\
\hline 1 & Chi Square & Diharapkan & 229,958 & Baik
\end{tabular}




\begin{tabular}{|c|c|c|c|c|}
\hline & & Kecil & & \\
\hline 2 & $\begin{array}{l}\text { Goodness of Fit Index } \\
\text { (GFI) }\end{array}$ & $>0,90$ & 0,874 & Marginal \\
\hline 3 & $\begin{array}{l}\text { Adjusted Goodness of } \\
\text { Fit Index (AGFI) }\end{array}$ & $>0,90$ & 0,833 & Marginal \\
\hline 4 & $\begin{array}{l}\text { Tucker Lewis Index } \\
\text { (TLI) }\end{array}$ & $>0,90$ & 0,984 & Baik \\
\hline 5 & $\begin{array}{l}\text { Comparative } \quad \text { Fit } \\
\text { Index }(\mathrm{CFI})\end{array}$ & $>0.90$ & 0,987 & Baik \\
\hline 6 & $\begin{array}{l}\text { Root Mean Square } \\
\text { Error of } \\
\text { Approximation } \\
\text { (RMSEA) }\end{array}$ & $\leq 0,08$ & 0,029 & Baik \\
\hline 7 & CMIN/DF & $\leq 2$ & 1,106 & Baik \\
\hline 8 & $p$-value & $>0,05$ & 0,142 & Baik \\
\hline
\end{tabular}

Tabel tersebut menunjukkan bahwa nilai GFI dan AGFI berada pada posisi marginal dan yang lainnya berada pada posisi yang baik. Hal tersebut terlihat jelas dengan nilai $p$-value yang berada di atas 0,142 sehingga model ini layak untuk diestimasikan.

\section{ESTIMASI MODEL DAN PENGUJIAN HIPOTESIS}

Berdasarkan hasil Full Model setelah modifikasi, maka nilai koefisien, critical ratio dan $p$-value antar variabel eksogen terhadap variabel endogen dapat dilihat sebagai berikut:

\section{Tabel 5. Estimasi Regresi}

\begin{tabular}{lllllll}
\hline & & & Estimate & S.E. & C.R. & P \\
& & & & & & \\
\hline OCB & $\leftarrow-$ & Personality & 0,143 & 0,098 & 1,353 & 0,046 \\
OCB & $\leftarrow-$ & Budaya_Organisasi & 0,228 & 0,084 & 2,122 & 0,034 \\
OCB & $\leftarrow-$ & Komitmen_Organisasi & 0,028 & 0,088 & 0,267 & 0,789 \\
Kinerja_Guru & $\leftarrow-$ & Personality & 0,327 & 0,112 & 2,933 & 0,003 \\
Kinerja_Guru & $\leftarrow-$ & OCB & & & & \\
Kinerja_Guru & $\leftarrow-$ & Budaya_Organisasi & $-0,235$ & 0,093 & $-2,140$ & 0,032 \\
Kinerja_Guru & $\leftarrow-$ & Komitmen_Organisasi & $-0,059$ & 0,096 & $-0,560$ & 0,575
\end{tabular}

Berdasarkan Tabel 5, maka persamaan jalur yang dihasilkan adalah sebagai berikut:

$\mathrm{OCB}=0,143 \mathrm{P}+0,228 \mathrm{BO}+0,028 \mathrm{KO}$

$\mathrm{KG}=0,327 \mathrm{P}-0,237 \mathrm{BO}-0,059 \mathrm{KO}+0,262 \mathrm{OCB}$

Adapun Adapun bentuk pengaruh dan pengujian hipotesis antara variabel eksogen dengan variabel endogen adalah sebagai berikut:

1. Pengaruh Personality terhadap OCB

Berdasarkan hasil analisis SEM, nilai koefisien personality terhadap OCB sebesar 0,143 $(14,3 \%)$ yang menunjukkan bahwa ketika personality naik $1 \%$, maka OCB akan meningkat sebesar $14,3 \%$. Selanjutnya nilai tersebut signifikan secara statistik dengan $p$-value sebesar 0,046 , dimana nilai tersebut berada di bawah nilai toleransi kesalahan dalam penelitian ini $(0,05)$, sehingga $\mathrm{H}_{1}$ 
diterima yang artinya personality berpengaruh positif terhadap OCB pada sekolah menengah di Kecamatan Indra Makmur.

2. Pengaruh Budaya Organisasi terhadap OCB

Berdasarkan hasil analisis SEM, nilai koefisien budaya organisasi terhadap OCB sebesar $0,228(22,8 \%)$ yang menunjukkan bahwa ketika budaya organisasinaik $1 \%$, maka OCB akan meningkat sebesar $22,8 \%$. Selanjutnya nilai tersebut signifikan secara statistik dengan $p$-value sebesar 0,034 dimana nilai tersebut berada di bawah nilai toleransi kesalahan dalam penelitian ini $(0,05)$, sehingga $\mathrm{H}_{2}$ diterima yang artinya budaya organisasi berpengaruh positif terhadap OCB pada sekolah menengah di Kecamatan Indra Makmur.

\section{Pengaruh Komitmen Organisasi terhadap OCB}

Berdasarkan hasil analisis SEM, nilai koefisien komitmen organisasi terhadap OCB sebesar $0,028(2,8 \%)$ yang menunjukkan bahwa ketika komitmen organisasinaik $1 \%$, maka OCB akan meningkat sebesar $2,8 \%$. Akan tetapi, nilai tersebut tidak signifikan secara statistik dengan $p$-value sebesar 0,789 dimana nilai tersebut berada di atas nilai toleransi kesalahan dalam penelitian ini $(0,05)$, sehingga $\mathrm{H}_{3}$ ditolak yang artinya komitmen organisasitidak berpengaruh signifikan terhadap OCB pada sekolah menengah di Kecamatan Indra Makmur.

4. Pengaruh Personality terhadap Kinerja Guru

Berdasarkan hasil analisis SEM, nilai koefisien personality terhadap kinerja guru sebesar $0,327(32,7 \%)$ yang menunjukkan bahwa ketika personality naik $1 \%$, maka kinerja guru akan meningkat sebesar $32,9 \%$. Selanjutnya, nilai tersebut signifikan secara statistik dengan $p$-value sebesar 0,003 dimana nilai tersebut berada di bawah nilai toleransi kesalahan dalam penelitian ini $(0,05)$, sehingga $\mathrm{H}_{4}$ diterima yang artinya personality berpengaruh positif terhadap kinerja guru pada sekolah menengah di Kecamatan Indra Makmur.

5. Pengaruh Budaya Organisasi terhadap Kinerja Guru

Berdasarkan hasil analisis SEM, nilai koefisien budaya organisasi terhadap kinerja guru sebesar $-0,237(-23,7 \%)$ yang menunjukkan bahwa ketika budaya organisasi naik $1 \%$, maka kinerja guru akan menurun sebesar $23,7 \%$. Selanjutnya, nilai tersebut signifikan secara statistik dengan $p$ value sebesar 0,032 dimana nilai tersebut berada di bawah nilai toleransi kesalahan dalam penelitian ini $(0,05)$, sehingga $\mathrm{H}_{5}$ diterima yang artinya budaya organisasi berpengaruh negatif terhadap kinerja guru pada sekolah menengah di Kecamatan Indra Makmur.

6. Pengaruh Komitmen Organisasi terhadap Kinerja Guru

Berdasarkan hasil analisis SEM, nilai koefisien komitmen organisasi terhadap kinerja guru sebesar $-0,059(-5,9 \%)$ yang menunjukkan bahwa ketika komitmen organisasi naik $1 \%$, maka kinerja guru akan menurun sebesar 5,9\%. Akan tetapi, nilai tersebut tidak signifikan secara statistik dengan $p$ value sebesar 0,575 dimana nilai tersebut berada di atas nilai toleransi kesalahan dalam penelitian ini $(0,05)$, sehingga $\mathrm{H}_{6}$ ditolak yang artinya komitmen organisasi tidak berpengaruh signifikan terhadap kinerja guru pada sekolah menengah di Kecamatan Indra Makmur.

7. Pengaruh OCB terhadap Kinerja Guru

Berdasarkan hasil analisis SEM, nilai koefisien OCB terhadap kinerja guru sebesar 0,262 $(26,2 \%)$ yang menunjukkan bahwa ketika OCB naik $1 \%$, maka kinerja guru akan meningkat sebesar $26,2 \%$. Selanjutnya, nilai tersebut signifikan secara statistik dengan $p$-value sebesar 0,013 dimana nilai tersebut berada di bawah nilai toleransi kesalahan dalam penelitian ini $(0,05)$, sehingga $\mathrm{H}_{7}$ diterima yang artinya OCB berpengaruh positif terhadap kinerja guru pada sekolah menengah di Kecamatan Indra Makmur.

\section{Uji Efek Mediasi}

Model mediasi pertama sekali diperkenalkan oleh Baron \& Kenny (1986), menjelaskan prosedur analisis variabel mediator secara sederhana melalui regresi. Intinya, menurut Baron \& Kenny (1986) mensyaratkan bahwa sebuat variabel dapat dikatakan menjadi mediator jika hasilnya adalah Jalur -c signifikan, Jalur -a signifikan, jalur - b signifikan dan jalur -c' tidak signifikan maka disebut sebagai full mediation. Tetapi jika jalur $-\mathrm{a},-\mathrm{b}$, dan $-\mathrm{c}$ signifikan dan jalur $-\mathrm{c}$ ' signifikan maka disebut dengan partial mediation.

Dalam penelitian ini, terdapat 3 hipotesis pengaruh mediasi yang akan diuji, yaitu $\mathrm{H}_{8}-\mathrm{H}_{10}$. Adapun hasil pengujian ketiga hipotesis tersebut adalah sebagai berikut:

1. OCB memediasi pengaruh personality terhadap kinerja guru 
Hasil pengujian efek mediasi hubungan personality dengan kinerja guru melalui OCB dapat memenuhi syarat, dikarenakan jalur $-\mathrm{a}$, $-\mathrm{b}$ dan $-\mathrm{c}$ signifikan secara statistik. Untuk melihat nilai signifikansi pada jalur -c', maka perhitungan dilakukan menggunakan kalkulator sobel. Adapun hasil pengujian mediasi pada Hipotesis 8 adalah sebagai berikut:

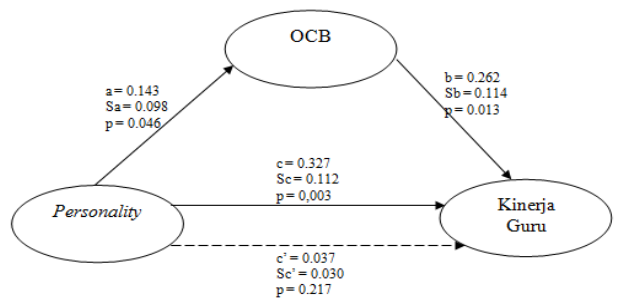

\section{Gambar 4 OCB memediasi Hubungan Personality dan Kinerja guru}

Berdasarkan Gambar 4, terlihat bahwa nilai koefisien c' memiliki nilai p-value sebesar 0,217 dimana nilai tersebut tidak signifikan secara statistik dikarenakan berada di atas nilai toleransi kesalaham, yaitu 0,05. Ini menunjukkan bahwa dalam hubungan personality dengan kinerja guru, OCB merupakan variabel yang mampu memediasi secara penuh (full mediation). Oleh karena itu, dapat disimpulkan bahwa OCB mampu memediasi pengaruh personality terhadap kinerja guru sehingga $\mathrm{H}_{8}$ diterima.

2. OCB memediasi pengaruh budaya organisasi terhadap kinerja guru

Hasil pengujian efek mediasi hubungan budaya organisasi dengan kinerja guru melalui OCB dapat memenuhi syarat, dikarenakan jalur -a, -b dan -c signifikan secara statistik. Untuk melihat nilai signifikansi pada jalur -c', maka perhitungan dilakukan menggunakan kalkulator sobel. Adapun hasil pengujian mediasi pada Hipotesis 9 adalah sebagai berikut:

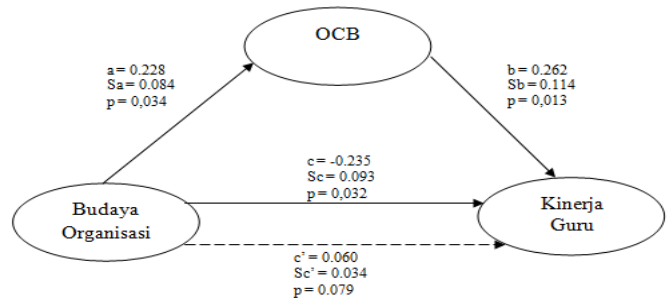

\section{Gambar 5 OCB memediasi Hubungan Budaya organisasi dan Kinerja Guru}

Berdasarkan Gambar 5, terlihat bahwa nilai koefisien c' memiliki p-value sebesar 0.079 dimana nilai tersebut tidak signifikan secara statistik karena berada di atas nilai toleransi kesalahan dalam penelitian ini $(0,05)$. Hasil ini menunjukkan bahwa OCB mampu memediasi pengaruh budaya organisasi terhadap kinerja guru, dimana peran mediasi OCB adalah memediasi secara penuh Full Mediation, sehingga $\mathrm{H}_{9}$ diterima.

3. OCB memediasi pengaruh komitmen organisasi terhadap kinerja guru

Hasil pengujian efek mediasi hubungan komitmen organisasi dengan kinerja guru melalui OCB tidak dapat memenuhi syarat, dikarenakan jalur $-\mathrm{a}$, dan $-\mathrm{c}$ signifikan tidak berpengaruh signifikan, sehingga nilai p-value untuk pengaruh tidak langsung komitmen organisasi terhadap kinerja tidak diperlu diketahui. Untuk lebih jelasnya, dapat dilihat pada gambar di bawah ini:

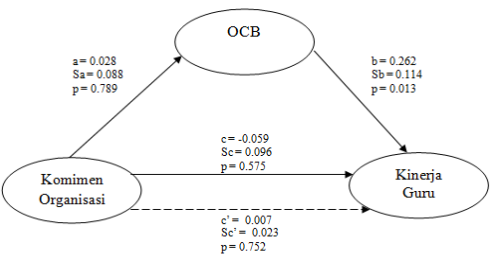




\section{Gambar 6 OCB tidak memediasi hubungan Komitmen Organisasi dan Kinerja Guru}

Berdasarkan Gambar 5.16, terlihat bahwa komitmen organisasi tidak berpengaruh signifikan terhadap OCB dan kinerja guru, sehingga OCB tidak mampu memediasi pengaruh komitmen organisasi terhadap kinerja guru, maka $\mathrm{H}_{10}$ ditolak.

\section{Pembahasan}

\section{Pengaruh Personality terhadap OCB}

Berdasarkan hasil penelitian yang telah dilakukan, ditemukan bahwa personality berpengaruh positif dan signifikan terhadap OCB pada guru sekolah menengah di Kecamatan Indra Makmur, Kabupaten Aceh Timur. Hal ini menunjukkan bahwa semakin tinggi kepribadian guru maka perilaku ekstra peran antar guru akan tercipta. Sementara itu, hasil analisis deksriptif jawaban responden membuktikan bahwa indikator ke 5 (keterbukaan terhadap pengalaman) menjadi indikator dengan nilai rata-rata tertinggi dalam menjelaskan variabel kepribadian guru. Hal ini menunjukkan bahwa guru yang selalu menerima dan berbagi pengalaman merupakan guru dengan tingkat kepribadian yang baik.

Hasil penelitian ini mengindikasikan bahwa kepribadian menjadi variabel yang dapat mendorong peningkatan perilaku sukarela guru. Tingginya kepribadian guru membuatnya menjadi lebih peka dan peduli terhadap lingkungan kerjanya. Selain itu, guru dengan tingkat kepribadian yang tinggi akan selalu berempati dalam membantu rekan-rekannya dalam mengajar. Hal ini dikarenakan kepribadian guru yang baik membuat guru menjadi lebih mengutamakan kepentingan umum dari pada kepentingan pribadinya.

Hasil penelitian ini sejalan dengan yang ditemukan oleh Najari et al. (2011), Sjahruddin et al. (2013) dan Fahmi (2017) yang mendokumentasikan bahwa kepribadian berpengaruh positif terhadap perilaku ekstra peran. Akan tetapi, hasil penelitian ini bertolak belakang dengan yang ditemukan oleh Purba \&Seniati (2010) yang mendokumentasikan bahwa kepribadian tidak berpengaruh signifikan terhadap perilaku ekstra peran.

\section{Pengaruh Budaya Organisasi terhadap OCB}

Penelitian ini menemukan bahwa budaya organisasi berpengaruh positif dan signifikan terhadap OCB pada sekolah menengah yang ada di Kecamatan Indra Makmur Kabupaten Aceh Timur. Artinya semakin baik budaya organisasi maka perilaku ekstra peran akan semakin meningkat. Sementara itu, indikator budaya organisasi yang memiliki nilai mean tertinggi adalah indikator ke 6 (Filosofi). Hal ini menunjukkan bahwa filosofi yang dimiliki oleh seorang guru menjadi faktor yang paling dominan dalam menjelaskan budaya organisasi di lingkungan sekolah.

Hasil penelitian ini menemukan budaya organisasi yang baik menjadi faktor yang dapat menciptakan perilaku ekstra peran guru. Norma dan nilai yang dijunjung tinggi akan menjadikan guru selalu bertindak dalam membantu rekan kerjanya demi tercapainya tujuan organisasi. Jones (2010) juga berpendapat bahwa kepatuhan anggota organisasi pada nilai dan norma yang berlaku menjadikan interaksi antar anggota menjadi semakin erat, sehingga perilaku tolong menolong secara sukarela akan tercipta.

Hasil penelitian ini sejalan dengan temuan Oemar (2013), Purnama (2013) dan Darsana (2013) yang mendokumentasikan bahwa budaya organisasi berpengaruh positif dan signifikan terhadap perilaku ekstra peran. Sementara itu, hasil penelitian ini bertolak belakang dengan temuan Hamza (2015) yang menemukan bahwa budaya organisasi tidak berpengaruh signifikan terhadap OCB.

\section{Pengaruh Komitmen Organisasi terhadap OCB}

Berdasarkan hasil penelitian yang telah dilakukan, ditemukan bahwa komitmen organisasi tidak berpengaruh signifikan terhadap OCB pada sekolah menengah di Kecamatan Indra Makmur, Kabupaten Aceh Timur. Hal ini menunjukkan bahwa komitmen organisasi bukanlah faktor pembentuk OCB di lingkungan sekolah. Selanjutnya, nilai rata-rata terendah pada indikator komitmen organisasi terdapat pada indikator pertama (kepercayaan kuat terhadap nilai dan tujuan organisasi). Hal ini menunjukkan bahwa masih rendahnya kepercayaan para guru di sekolah menengah Kecamatan Indra Makmur terhadap nilai-nilai dan tujuan yang dibangun oleh sekolah. 
Hasil penelitian ini mengindikasikan bahwa perilaku ekstra peran akan tetap tercipta meskipun komitmen organisasi rendah. Perilaku ekstra peran sesungguhnya bermakna membantu rekan kerja pada tugas-tugas ekstra secara sukarela. Komitmen organisasi yang tinggi mengacu pada kesetiaan individu pada organisasinya. Seseorang yang commite tentunya enggan untuk berpindah ke organisasi lain. Komitmen tersebut membuat para anggota organisasi untuk mencari cara agar tetap bertahan dalam organisasinya, sehingga perilaku individualitik akan tercipta dan OCB tidak akan muncul.

Hasil penelitian ini sejalan dengan temuan Darmawati et al. (2013) Sambung (2014) dan Yanti \& Supartha (2017) yang menemukan bahwa komitmen organisasi tidak berpengaruh signifikan terhadap OCB. Akan tetapi, hasil ini bertolak belakang dengan temuan Oemar (2013) yang membuktikan bahwa komitmen organisasi berpengaruh positif dan signifikan terhadap OCB.

\section{Pengaruh Personality terhadap Kinerja Guru}

Hasil penelitian ini telah membuktikan bahwa kepribadian berpengaruh positif dan signifikan terhadap kinerja guru pada sekolah menengah di Kecamatan Indra Makmur, Kabupaten Aceh Timur. Hasil ini menunjukkan bahwa semakin baik kepribadian guru, maka kinerjanya akan semakin meningkat. Penelitian ini juga membuktikan bahwa kepribadian menjadi elemen penting dalam mempengaruhi kinerja pada seorang guru.

Guru dengan ciri-ciri bekerja keras, disiplin tinggi, giat dan bertanggung jawab akan memiliki suatu kinerja yang lebih tinggi dibandingkan dengan individu kebalikannya. Kepribadian individu dalam menjalani tugas yang dibebankan membuatnya lebih tenang dan memotivasinya untuk bekerja lebih baik, sehingga kinerja akan meningkat. Kepribadian juga melambangkan karakter dan bakat seseorang, dimana kepribadian yang baik akan menciptakan bakat yang baik dan kinerja meningkat.

Hasil penelitian ini sejalan dengan temuan Jiang et al. (2009), Sutomo (2013) dan Indarti et al. (2014) yang menemukan bahwa kepribadian memiliki pengaruh positif dan signifikan terhadap kinerja. Sementara itu, hasil penelitian ini betolak belakang dengan temuan Wicaksono \& Surjanti (2018) yang menemukan bahwa kepribadian tidak berpengaruh signifikan terhadap kinerja.

\section{Pengaruh Budaya Organisasi terhadap Kinerja Guru}

Hasil penelitian ini telah membuktikan bahwa budaya berpengaruh negatif dan signifikan terhadap kinerja guru pada sekolah menengah di Kecamatan Indra Makmur, Kabupaten Aceh Timur, dimana nilai koefisien tersebut berbeda dengan harapan penulis. Hal tersebut menunjukkan bahwa budaya organisasi menjadi faktor yang menurunkan kinerja organisasi, artinya semakin tinggi budaya organisasi maka kinerja guru akan semakin menurun.

Budaya organisasi berpengaruh negatif terhadap kinerja pada saat anggota organisasi didominasi oleh usia muda, dimana psikologisnya masih sering tidak sejalan dengan kebiasaankebiasaan yang terapkan dalam organisasi (Meng \& Berger, 2019). Berdasarkan hasil analisis deskriptif responden, terdapat 33,3\% responden yang tergolong masih muda dalam rentang usia 21-30 tahun. Ini menunjukkan bahwa budaya organisasi akan berdampak negatif terhadap kinerja ketika anggota organisasi salah mempersepsikan arti-arti dan tujuan-tujuan yang ada di dalam organisasi.

Naldo (2017) berpendapat bahwajika kegiatan rutin dalam suatu organisasi merupakan kegiatan yang tidak sesuai dan tidak dapat diterima oleh anggota organisasi, maka budaya organisasi malah dapat menurunkan kinerja. Dari hasil penelitian ini, terlihat bahwa nilai rata-rata indikator kegiatan rutin yang masih berada di bawah 3 yang menunjukkan bahwa kegiatan-kegiatan rutin yang diterapkan pihak sekolah tidak sejalan dengan prinsip-prinsip guru sehingga kinerja guru malah mengalami penurunan. Selain itu, Sriekaningsih (2017) berpendapat bahwa budaya organisasi menurunkan kinerja pada konflik antar anggota organisasi terjadi. Berdasarkan hasil penelitian ini, juga terlihat bahwa indikator sikap dan perilaku guru menjadi indikator terendah, yang artinya sikap guru satu ke guru lain masih rendah, sehingga hal tersebut mendorong penurunan kinerja guru.

Hasil ini sejalan dengan temuan Marganingsih dan Martani (2014), Satyawati dan Suartana (2014), Hasmin (2016) dan Yusuf (2016) yang menemukan bahwa budaya organisasi berpengaruh negatif terhadap kinerja. Akan tetapi, hasil penelitian ini bertolak belakang dengan temuan Shahzad et al. (2013) yang menemukan bahwa budaya organisasi berpengaruh positif dan signifikan terhadap kinerja.

\section{Pengaruh Komitmen Organisasi terhadap Kinerja Guru}


Hasil penelitian ini menemukan bahwa komitmen organisasi tidak berpengaruh signifikan terhadap kinerja guru sekolah menengah di Kecamatan Indra Makmur Kabupaten Aceh Timur. Ini menunjukkan bahwa komitmen organisasi bukanlah prediktor pembentuk kinerja guru. Kinerja guru tidak bergantung pada tingkat komitmen organisasi yang ada.

Komitmen organisasi dalam penelitian ini tidak terbukti sebagai elemen yang dapat meningkatkan kinerja guru. Hal ini dikarenakan masih rendahnya komitmen organisasi guru sekolah menengah di Kabupaten Indra Makmur. Hal ini juga menunjukkan bahwa permasalahan komitmen organisasi bukanlah menjadi isu penting bagi pada guru sekolah menengah di Kabupaten Indra Makmur, sehingga tidak memberikan dampak terhadap peningkatan kinerja.

Hasil penelitian ini sejalan dengan temuan Hana dan Firnanti (2013), Harwiki (2013), Supriyanto (2014) Bodroastuti \& Ruliaji (2016) dan Marsoit et al. (2018) yang menemukan bahwa komitmen organisasi tidak berpengaruh signifikan terhadap kinerja. Sementara itu, hasil penelitian ini bertolak belakang dengan temuan Khan et al. (2010) yang menemukan bahwa komitmen organisasi berpengaruh positif dan signifikan terhadap kinerja.

\section{Pengaruh OCB terhadap Kinerja Guru}

Hasil penelitian ini telah membuktikan bahwa OCB berpengaruh positif dan signifikan terhadap kinerja guru pada sekolah menengah di Kecamatan Indra Makmur, Kabupaten Aceh Timur, dimana nilai koefisien tersebut sejalan dengan yang penulis harapkan. Hal tersebut menunjukkan bahwa OCB menjadi faktor yang menurunkan kinerja guru, artinya semakin tinggi OCB maka kinerja guru akan semakin meningkat.

Munculnya keefisienan dan keefektifan atau fungsi-fungsi organisasi merupakan dampak positif yang bersumber dari kinerja-kinerja pegawai dimaksud. Pegawai yang sering membantu tugastugas ekstra secara sukarela akan menunjukkan perilaku gemar membantu rekan kerja sehingga kinerja pegawai yang dibantu dapat meningkat. Farooqui (2012) berpandangan bahwa pegawai yang menunjukkan perilaku OCB dapat membantu meningkatkan kinerja para pegawai karena perilaku ini merupakan faktor yang mampu meningkatkan kinerja dalam mencapai tujuan organisasi.

Hasil penelitian ini sejalan dengan yang ditemukan oleh Fitriastuti (2013), Darsana (2013) dan Sani (2013) yang mendokumentasikan bahwa OCB berpengaruh positif dan signifikan terhadap kinerja guru. Sementara itu, hasil penelitian ini bertolak belakang dengan temuan Ramadhan et al. (2018) yang menemukan bahwa OCB tidak berpengaruh signifikan terhadap kinerja.

\section{OCB memediasi Pengaruh Personality terhadap Kinerja Guru}

Berdasarkan hasil analisis dengan menggunakan sobel test, dapat diketahui bahwa disiplin OCB memediasi pengaruh personality terhadap kiner guru, dimana nilai signifikansi yang diperoleh dari sobel test berada di atas nilai toleransi kesalahan dalam penelitian ini $(0,05)$. Maka dari itu, dapat disimpulkan bahwa OCB memberikan efek mediasi secara penuh pada pengaruh personality terhadap kinerja guru sekolah menengah di Kecamatan Indra Makmur.

Hasil penelitian ini menunjukkan bahwa OCB menjadi elemen perantara antara kepribadian guru dengan kinerja guru. Dengan tingginya perilaku ekstra peran yang dilakukan oleh para guru secara sukarela, maka mampu mempu menghantarkan pengaruh kepribadian terhadap peningkatan kinerja guru. Hal ini sejalan dengan hasil penelitian Darsana (2013) dan Soepono dan Srimulyani (2015) yang mendokumentasikan bahwa OCB mampu memediasi pengaruh kepribadian terhadap kinerja.

\section{OCB memediasi Pengaruh Budaya Organisasi terhadap Kinerja Guru}

Berdasarkan hasil analisis dengan menggunakan sobel test, dapat diketahui bahwa disiplin OCB memediasi pengaruh budaya organisasi terhadap kinerja guru, dimana nilai signifikansi yang diperoleh dari sobel test berada di atas nilai toleransi kesalahan dalam penelitian ini $(0,05)$. Maka dari itu, dapat disimpulkan bahwa OCB memberikan efek mediasi secara penuh pada pengaruh budaya organisasi terhadap kinerja guru sekolah menengah di Kecamatan Indra Makmur.

Hasil ini membuktikan bahwa perilaku ekstra peran menjadi elemen yang dapat memediasi hubungan budaya organisasi dengan kinerja guru. Melalui perilaku ekstra peran, pengaruh budaya organisasi terhadap kinerja guru dapat tercipta dengan baik. Hasil ini sejalan dengan temuan Harwiki (2013) dan Maulani et al (2015) yang mendokumentasikan bahwa OCB memediasi pengaruh budaya organisasi terhadap kinerja.

\section{OCB memediasi Pengaruh Komitmen Organisasi terhadap Kinerja Guru}


Hasil penelitian menunjukkan bahwa OCB bukanlah mediator pada hubungan komitmen organisasi terhadap kinerja guru sekolah menengah di Kecamatan Indra Makmur. Hal ini dapat dilihat dari tidak terpenuhinya kriteria mediasi, dimana secara langsung komitmen organisasi tidak berpengaruh signifikan terhadap OCB dan kinerja guru, sehingga dapat diambil kesimpulan bahwa OCB bukanlah mediator pada hubungan komitmen organisasi terhadap kinerja guru.

Hasil penelitain ini mengindikasikan bahwa OCB bukanlah elemen yang menjadi mediator dalam pengaruh komitmen organisasi terhadap kinerja guru. Hal ini sejalan dengan hasil penelitian Setyowati et al. (2015) yang menemukan bahwa OCB tidak menjadi mediator pada hubungan komitmen organisasi terhadap kinerja.

\section{KESIMPULAN}

Berdasarkan hasil analisis data yang telah dilakukan, maka kesimpulan yang dapat diambil dari penelitian ini adalah sebagai berikut:

1. Personality berpengaruh positif dan signifikan terhadap OCB pada sekolah menengah di Kecamatan Indra Makmur.

2. Budaya organisasi berpengaruh positif dan signifikan terhadap OCB pada sekolah menengah di Kecamatan Indra Makmur.

3. Komitmen organisasi tidak berpengaruh signifikan terhadap OCB pada sekolah menengah di Kecamatan Indra Makmur.

4. Personality berpengaruh positif dan signifikan terhadap kinerja guru pada sekolah menengah di Kecamatan Indra Makmur.

5. Budaya organisasi berpengaruh positif dan signifikan terhadap kinerja guru pada sekolah menengah di Kecamatan Indra Makmur.

6. Komitmen organisasi tidak berpengaruh signifikan terhadap kinerja guru pada sekolah menengah di Kecamatan Indra Makmur.

7. OCB berpengaruh positif dan signifikan terhadap kinerja guru pada sekolah menengah di Kecamatan Indra Makmur.

8. OCB memediasi penuh pengaruh personality terhadap kinerja guru pada sekolah menengah di Kecamatan Indra Makmur.

9. OCB memediasi penuh pengaruh budaya organisasi terhadap kinerja guru pada sekolah menengah di Kecamatan Indra Makmur.

10. OCB tidak memediasi pengaruh komitmen organisasi terhadap kinerja guru pada sekolah menengah di Kecamatan Indra Makmur.

\section{SARAN}

Adapun beberapa saran dan masukan yang dapat diberikan kepada beberapa pihak adalah sebagai berikut;

1. Indikator terendah untuk variabel kepribadian adalah tingkat kemudahan dalam bersepat, maka disarankan kepada pihak pimpinan sekolah untuk menciptakan keakraban antar sesama guru, seperti membuat kegiatan-kegiatan yang dapat meningkatkan keakraban sesama guru.

2. Indikator terendah untuk variabel budaya organisasi adalah kebiasaan dan kegiatan bersifat rutin, sehingga disarankan kepada pihak sekolah untuk lebih membuat kegiatan-kegiatan positif demi menciptakan budaya organisasi yang baik, seperti kegiatan pengajian antar guru, kegiatan silaturahmi dan lain-lain.

3. Indikator terendah untuk variabel komtimen organisasi adalah kepercayaan yang kuat dan penerimaan terhadap nilai-nilai dan tujuan organisasi, sehingga disarankan kepada pihak sekolah untuk lebih terbuka kepada para guru dan melibatkan guru dalam kebijakan-kebijakan sekolah agar komitmen organisasi guru lebih baik.

4. Indikator terendah untuk variabel OCB adalah inisiatif membatu rekan kerja secara sukarela, sehingga disarankan kepada pihak sekolah untuk lebih meningkatkan komunikasi antar guru dan memberikan imbalan atas kerja guru yang secara sukarela membantu kegiatan sekolah padahal itu diluar jam kerjanya.

5. Indikator terendah untuk variabel kinerja guru adalah Perencanaan pembelajaran, sehingga disarankan kepada pihak sekolah untuk menciptakan dan meningkatkan perencanaan program 
belajar mengajar setiap tahun ajaran dengan menerima masukan-masukan guru agar kinerja para guru dapat lebih optimal

6. Komitmen organisasi tidak berpengaruh signifikan terhadap OCB dan kinerja guru, sehingga disarankan kepada peneliti selanjutnya untuk mengkaji kembali faktor-faktor yang mempengaruhi OCB dan kinerja guru dengan variabel-variabel lain seperti motivasi kerja, lingkungan kerja, gaya kepemimpinan kepala sekolah ataupun kompetensi guru.

\section{DAFTAR REFERENSI}

Ridwan. A. Hadi Arifin dan Aiyub. (2018). Pengaruh Motivasi Kerja, Iklim Organisasi Dan Stres Kerja Terhadap Kinerja Guru SMAN/SMKN Pada UPTD Matangkuli dan Tanah Luas dengan Kepuasan Kerja Sebagai Variabel Intervening. Jurnal Manajemen Indonesia. Vol 3. No 2.

Brewster, C., Gooderham, P. N., \& Mayrhofer, W. (2016). Human resource management: The promise, the performance, the consequences. Journal of Organizational Effectiveness: People and Performance, 3(2), 181-190.

Mondiani, Tria. (2012). Pengaruh Kepemimpinan Transformasional dan Kompensasi Terhadap Kinerja Karyawan PT. PLN (PERSERO) UPJ SEMARANG. Jurnal Administrasi Bisnis Volume I Nomor 1.

Manurung, N., \& Riani, A. L. (2017). Pengaruh Disiplin Kerja, Motivasi Kerja, Kepuasan Kerja dan Kompetensi Terhadap Komitmen Organisasi. Jurnal Manajemen Dayasaing, 18(1), 10-19.

Manzoor, S. R., Ullah, H., Hussain, M., \& Ahmad, Z. M. (2011). Effect of teamwork on employee performance. International Journal of Learning and Development, 1(1), 110-126.

Matriadi dan Dalimunthe, (2017). Analyzing the Compensation and Competence on Senior High School Teacher's Performance through the Mediating Role of Job Motivation. Advanced in Economi, Business and Management Reasearch (AEBMR), volume 46

Mangkunegara, Prabu.A.A (2009), Manajemen Sumber Daya Manusia Perusahaan, Cetakan Keenam, PT. Remaja Rosdakarya, Bandung.

Mahmudi, M. (2010). Manajemen Kinerja Sektor Publik.UPP STIM YKPN, Yogyakarta

Mulyani dan Soliha (2014). Pengaruh Karakteristik Pekerjaan Dan Motivasi Terhadap Komitmen Organisasional Serta Dampaknya Terhadap Kinerja Guru (Studi di SMP Negeri 21 dan SMP Negeri 26 Semarang). Performance - Vol. 20 No. 2 September 2014

Bambale, A. J. A., Shamsudin, F. M., \& Subramaniam, C. A. (2012). Servant Leadership as Employee-Organization Approach for Performance of Employee Citizenship Behaviors in the Nigeria's Electric Power Sector. Journal of Marketing and Management, 3(1), 1.

Khan, M. R., Ziauddin, J. F., \& Ramay, M. I. (2010). The impacts of organizational commitment on employee job performance. European Journal of Social Sciences, 15(3), 292-298.

Tindowen, D. J. (2019). Influence of Empowerment on Teachers' Organizational Behaviors. European Journal of Educational Research, 8(2), 617-631. doi: 10.12973/eu-jer.8.2.617.

Minarsih (2015). Analisis Pengaruh Kepemimpinan Transformasional, Moral Dan Komitmen Organisasi Terhadap Organizational Citizenship Behavior Dalam Meningkatkan Kinerja Guru Sekolah Dasar Swast A Di Kecamat An Pedurungan Kota Semarang. Jurnal Ekonomi dan Bisnis Kontemporer, 2015- jurnal.unpand.ac.id

Ngatinah dan Purnami (2019). Kontribusi Komunikasi Intepersonal, Kecerdasan Emosional Dan Komitmen Organisasi Sekolah Terhadap Kinerja Guru SD. SOSIOHUMANIORA - Vol. 5, No.1, Februari 2019 - Jurnal LP3M - Universitas Sarjanawiyata Tamansiswa Yogyakarta

Yusuf, M. (2016). Pengaruh Gaya Kepemimpinan Dan Budaya Organisasi Terhadap Kepuasan Kerja Dan Kinerja Guru Militer Resimen Induk Komando Daerah Militer Vii/Wirabuana Di Sulawesi. Jurnal BISNIS \& KEWIRAUSAHAAN, 5(2).

Wicaksono, A. T., \& Surjanti, J. (2018). Pengaruh Dimensi Kepribadian terhadap Kinerja Karyawan dengan Pelatihan sebagai Variabel Mediasi Studi pada PT Gresik Cipta Sejahtera. BISMA (Bisnis dan Manajemen), 9(1), 33-42.

Shahzad, F. (2014). Impact of organizational culture on employees' job performance: An empirical study of software houses in Pakistan. International Journal of Commerce and Management, 24(3), 219-227. 
Ticoalu (2013). Organizational Citizenship Behavior (Ocb) Dan Komitmen Organisasi Pengaruhnya Terhadap Kinerja Karyawan. Jurnal EMBA Vol.1 No.4 Desember 2013, Hal. 782-790

Ramadhan, F. P., Susilo, H., \& Aini, E. K. (2018). Pengaruh Organizational Citizenship Behavior (OCB) dan Good Corporate Governance (GCG) Terhadap Kinerja Karyawan (Studi Pada Karyawan PT. TASPEN (Persero) Kantor Cabang Malang). Jurnal Administrasi Bisnis, 55(2), 152-159.

Sutomo, Y. (2013). Pengaruh Kepribadian dan Motivasi Kerja terhadap Kinerja Guru Dimoderasi Budaya Organisasi pada Madrasah Tsanawiyah Swasta Kecamatan Winong Kabupaten Pati. Jurnal Mahasiswa Pasca Sarjana Stikubank.

Wardani, A. K., \& Suseno, M. N. M. (2012). Faktor Kepribadian Dan Organizational Citizenship Behavior Pada Polisi Pariwisata. Humanitas, 9(2), 193-204.

Kumar, K., Bakhshi, A., \& Rani, E. (2009). Linking the 'Big Five'personality domains to Organizational citizenship behavior. International journal of Psychological studies, 1(2), 73.

Najari, R., Ahmadi, F., \& Habibitabar, Z. (2011). Study of relationship between personality and organizational citizenship behaviour (OCB) in public organizations in Iran. Interdisciplinary Journal of Contemporary Research in Business, 3(2), 472-483.

Oemar (2013). Pengaruh Budaya Organisasi, Kemampuan Kerja dan Komitmen Organisasi terhadap Organizational Citizenhsip Behavior (OCB) Pegawai pada BAPPEDA Kota Pekanbaru. Jurnal Aplikasi Manajemen Volume 11 Nomor 1 Maret 2013.Universitas Riau.

Lambert, E. G., Hogan, N. L., \& Griffin, M. L. (2008). Being the good soldier: Organizational citizenship behavior and commitment among correctional staff. Criminal justice and behavior, 35(1), 56-68.

Jo, S. J., \& Joo, B. K. (2011). Knowledge sharing: The influences of learning organization culture, organizational commitment, and organizational citizenship behaviors. Journal of Leadership \& Organizational Studies, 18(3), 353-364.

Luthans, F. (2006), Perilaku Organisasi (organizational Behavior), Edisi 10, Penerjemah Vivin Andhika Yuwono, Shekar Purwanti, Th, Arie P, Winong Rosari, Penerbit ANDI, Yogyakarta.

Poropat, A. E. (2009). A meta-analysis of the five-factor model of personality and academic performance. Psychological bulletin, 135(2), 322.

Jiang, C., Wang, D., \& Zhou, F. (2009). Personality traits and job performance in local government organizations in China. Social Behavior and Personality: an international journal, 37(4), 451-457.

Indrawijaya, Ibrahim.A. (2010), Teori, Perilaku, dan Budaya Organisasi, Cetakan Pertama, PT. Refika Aditama, Bandung

Robbins, P.S (2006). Perilaku Organisasi Edisi Lengkap: Organizational Behavior Tenth Edition, Penerjemah Benyamin Molan. PT. Index Jakarta.

Shahzad, F. (2014). Impact of organizational culture on employees' job performance: An empirical study of software houses in Pakistan. International Journal of Commerce and Management, 24(3), 219-227.

Harwiki (2013). The Influence of Servant Leadership on Organization Culture, Organizational Commitment, Organizational Citizenship Behavior (OCB) and Employees' Performance (study of Outstanding Cooperatives in East Java Province, Indonesia). Proceedings of 4th International Conference on Education and Information Management (ICEIM-2013)

Khan, M. R., Ziauddin, J. F., \& Ramay, M. I. (2010). The impacts of organizational commitment on employee job performance. European Journal of Social Sciences, 15(3), 292-298.

Bambale, A. J. A., Shamsudin, F. M., \& Subramaniam, C. A. (2012). Servant Leadership as Employee-Organization Approach for Performance of Employee Citizenship Behaviors in the Nigeria's Electric Power Sector. Journal of Marketing and Management, 3(1), 1.

Griffin, R., \& Moorhead, G. (2014). Organizational Behavior, Managing people and Organizations.(En línea). CA. Consultado, 08 sept. 2015.

Tehran, M.G, Abtahi, M. S., \& Esmaeili, S. (2013). The relationship between organizational citizenship behavior and performance of the staff of Qazvin University of Medical Sciences 
and Health Services. International Journal of Academic Research in Business and Social Sciences, 3(9), 534.

Baron, R. M., \& Kenny, D. A. (1986). The Moderator-Mediator Variable Distinction in Social Psychological Research: Conceptual, strategic, and statistical considerations. Journal of personality and social psychology, 51(6), 1173. 